\title{
Apis mellifera (Hymenoptera: Apidae) as a potential Brassica napus pollinator (cv. Hyola 432) (Brassicaceae), in Southern Brazil
}

\author{
Rosa, AS. ${ }^{\text {a }}$, Blochtein, B. ${ }^{\mathrm{a}}$, Ferreira, NR. ${ }^{\mathrm{a}}$ and Witter, $S .{ }^{\mathrm{b}}$ \\ ${ }^{a}$ Departamento de Biodiversidade e Ecologia, Faculdade de Biociências, \\ Laboratório de Entomologia, Pontifícia Universidade Católica do Rio Grande do Sul - PUCRS, \\ Av. Ipiranga, 6681, CEP 90619-900, Porto Alegre, RS, Brazil \\ ${ }^{b}$ Centro de Meteorologia Aplicada, Fundação Estadual de Pesquisa e Agropecuária - FEPAGRO, \\ Rua Gonçalves Dias, 570, Menino Deus, CEP 90130-060, Porto Alegre, RS, Brazil \\ *e-mail: annesouzar@gmail.com \\ Received May 13, 2009 - Accepted July 28, 2009 - Distributed November 30, 2010
}

(With 10 figures)

\begin{abstract}
Brassica napus Linnaeus is considered a self-compatible crop; however, studies show that bee foraging elevates their seed production. Considering bee food shortages during the winter season and that the canola is a winter crop, this study aimed to evaluate the foraging behaviour of Apis mellifera Linnaeus, 1758 regarding those flowers, and to verify if it presents adequate behaviour for successfully pollinating this crop in Rio Grande do Sul State. The study was carried out in a canola field, in Southern Brazil. The anthesis stages were morphologically characterised and then related to stigma receptivity and pollen grain viability. Similarly, the behaviour of A. mellifera individuals on flowers was followed, considering the number of flowers visited per plant, the amount of time spent on the flowers, touched structures, and collected resources. Floral fidelity was inferred by analysing the pollen load of bees collected on flowers. The bees visited from 1-7 flowers/plant $(\overline{\mathrm{x}}=2.02 ; \mathrm{sd}=1.16)$, the time spent on the flowers varied between $1-43$ seconds $(\overline{\mathrm{x}}=3.29 ; \mathrm{sd}=2.36)$ and, when seeking nectar and pollen, they invariably touched anthers and stigmas. The pollen load presented $100 \%$ of B. napus pollen. The bees' attendance to a small number of flowers/plants, their short permanence on flowers, their contact with anthers and stigma and the integral floral constancy allows their consideration as potential B. napus pollinators.
\end{abstract}

Keywords: behavior, canola, honey bees, anthesis, pollination.

\section{Apis mellifera (Hymenoptera: Apidae) como potencial polinizador de Brassica napus (cv. Hyola 432) (Brassicaceae), no Sul do Brasil}

\section{Resumo}

Brassica napus Linnaeus é considerada uma cultura autocompatível, entretanto, estudos indicam que o forrageio de abelhas eleva sua produtividade de sementes. Considerando-se a escassez de alimento para abelhas no inverno e a canola sendo uma cultura desse período, objetivou-se avaliar o comportamento de forrageio de Apis mellifera Linnaeus, 1758 nas suas flores e verificar se apresenta comportamento propício ao sucesso de polinização dessa cultura no Rio Grande do Sul. O estudo foi desenvolvido em lavoura de canola, no Sul do Brasil. Os estágios da antese foram caracterizados morfologicamente e relacionados à receptividade do estigma e à viabilidade dos grãos de pólen. Paralelamente, o comportamento de indivíduos de A. mellifera nas flores foi acompanhado, considerando-se o número de flores visitadas por planta, o tempo de permanência nas flores, as estruturas tocadas e os recursos coletados. A fidelidade floral foi inferida analisando-se a carga polínica de abelhas coletadas em flores. As abelhas visitaram entre 1-7 flores/planta $(\overline{\mathrm{x}}=2,02 ; \mathrm{sd}=1,16)$, o tempo de permanência nas flores variou entre 1-43 segundos $(\overline{\mathrm{x}}=3,29 ; \mathrm{sd}=2,36)$ e, ao buscarem néctar e pólen, invariavelmente tocavam anteras e estigmas. A carga polínica apresentou $100 \%$ de pólen de $B$. napus. A visita a poucas flores/planta, a curta permanência sobre as flores, o contato das abelhas com anteras e estigma e a plena constância floral, permitem considerá-las como potenciais polinizadoras de B. napus.

Palavras-chave: comportamento, canola, abelhas melíferas, antese, polinização. 


\section{Introduction}

Canola (Canadian oil low acid) is a genetically modified selection of the Brassica napus Linnaeus colza, developed in Canada. This annual herbaceous species is the third most produced oleaginous plant in the world, being mainly consumed in developed countries (Tomm, 2005). In Rio Grande do Sul State, Brazil, it stands out as an excellent economic alternative for enabling the production of vegetable oils during the winter (Barni et al. 1985). An increasing interest in canola oil as a functional food source due to its excellent composition of fatty acids is observed (Cunha, 2007). Besides those attributes, the high level of oil in its seeds (40 to 46\%) (Albuquerque et al., 2007) makes it a good choice for the production of biodiesel (Albuquerque, 2006).

Seeking an increase in grain production worldwide, through technologies that consider weather-related aspects and vegetable nutrition, pollination is gradually being valued as studies indicated its contribution to farming (Imperatriz-Fonseca, 2004). The pollinators' efficiency in transferring pollen grains partially determines a species' reproductive success (Schlindwein et al., 2005). Insects represent important vectors in this process (Kevan and Eisikowitch, 1990). Most vegetables from the Brassicaceae family, which are commercially exploited, are represented by hybrids whose seed production depends on entomophilous pollination (Syafaruddin et al., 2006).

The pollinating efficiency of anthophilous insects is intimately related to the floral biology of the vegetable species and to their foraging behaviour (Flores and Trindade, 2007). For a pollinating agent to be effective, this behaviour should favour the transportation of anther pollen to flower stigmas on the same plant or different target species plants (Freitas and Paxton, 1996). Honey bees are included in this context, whose foraging behaviour is favourable to the increase of crop productivity (D'Ávila and Marchini, 2005).

Bees feed almost exclusively on pollen and nectar (Masierowska, 2003) and need to visit a great number of flowers in order to satisfy the colony's needs (Corbet et al., 1991). B. napus flowers are extremely attractive to them (Abrol, 2007) and its high level of attractiveness is related to its fragrance (Mussury and Fernandes, 2000) and to its abundant food resources (Williams, 1980; Mesquida et al., 1988).

B. napus flowers are monoclinous, having four sepals, four petals, four long stamens, and two short stamens. They have four nectaries, two in each pair of long stamens and two in the inner part of the short stamens (Free, 1993; Mussury and Fernandes, 2000). The latter secrete a greater amount of nectar, with high concentrations of sugars, and are more easily accessible to insects during the entire anthesis period (Williams, 1980).

Even though B. napus is considered a self-compatible crop (Williams, 1978; Eisikowitch, 1981), susceptible to wind pollination (Gene Technology Regulator, 2002), the foraging bees increase its productivity rate (McGregor, 1976; Delaplane and Mayer, 2000; Sabbahi et al., 2005).
Nevertheless, studies indicate that most of the insect fauna that visits B. napus consists of honey bees. In the state of Georgia (USA) those insects represent about $64 \%$ of flower visitors (Delaplane and Mayer, 2000), while in São Paulo State (Brazil) its representation reaches $81 \%$ (Adegas and Nogueira-Couto, 1992). Kevan and Eisikowitch (1990) emphasise the effectiveness of these bees in transferring pollen grains.

Considering bee food shortages during the low temperature periods in Rio Grande do Sul State, and that canola is a winter crop, this study aimed to evaluate the foraging behaviour of Apis mellifera Linnaeus, 1758 on B. napus flowers and to verify if they present a potential pollinating behaviour for this crop in the state of Rio Grande do Sul.

\section{Material and Methods}

\subsection{Area of study}

The study was conducted in 13 ha of commercial crops of B. napus cultivar Hyola 432, belonging to the Sociedade Educacional Três de Maio (Três de Maio Educational Society) (27 46' 24' S 54 14' 24' W), 13 km from the head office of the Três de Maio municipality, in Rio Grande do Sul State, Brazil. Data gathering was performed from July to August 2007, during the crop's flowering. This region has a moderate climate, being that temperature, precipitation and humidity averages reach, respectively, $14.6{ }^{\circ} \mathrm{C}, 2.8 \mathrm{~mm}$ and $74.6 \%$ during this period. Meteorological data were obtained from the applied meteorology center database of the Fundação Estadual de Pesquisa Agropecuária (FEPAGRO, State Foundation for Farming Research).

\subsection{Anthesis and stigma receptivity}

Flower development was studied on 80 flower buds in pre-anthesis, from 10 plants. From these 80 flower buds, 20 flowers were collected and analysed on a daily basis. The anthesis is the flower's opening period and the beginning of the stamen's and pistil's senescence (Faegri and Pij1, 1979).

From the marked flowers, the anthesis stages were characterised according to petal physiognomy, stamen position, dehiscence and pollen grain availability in anthers, stigma coloration and secretion and (using a digital caliper rule) pistil height.

Stigma receptivity was verified on eighty flowers marked in the pre-anthesis phase and collected (20 in each day) during all duration's flowers period (approximately 3 days). For this, the style of each flower was detached, using tweezers, and its tip immersed in a drop of hydrogen peroxide solution $(3 \%)$ placed on a histological slide immediately after its detachment from the flower. The formation of blisters was identified under a stereoscopic microscope, indicating receptive stigmas (Dafni, 2005).

\subsection{Pollen grain viability}

In order to verify the presence of cytoplasmic content from flowers that had been with receptive stigma, 45 flower 
buds from 10 plants were randomly marked. As of the beginning of anthesis, 15 flowers were collected and their pollen grains stained with acetic-carmine solution (Dafni, 2005) on a daily basis. Later, approximately 1.000 grains were counted under an optical microscope, in order to differentiate pollen grains with and without cytoplasmic content.

The pollen grain germination rate was estimated according to flower age, from 42 random flower buds pertaining to 10 plants. Following the methodology proposed by Bots and Mariani (2005), as of the beginning of anthesis, 14 flowers were collected and analysed on a daily basis: two anthers from each flower were put in a $100 \mu \mathrm{l}$ culture medium (PGM: $0.01 \% \mathrm{H}_{3} \mathrm{BO}_{3}, 0.07 \% \mathrm{CaCl} 2 \mathrm{H}_{2} 0,3.0 \%$ PEG 6000 and $20 \%$ saccharose), for pollen germination, and identified according to collection date, anthesis stage and duration of culture. After 2 and 4 hours of culture seven flowers were fixed with formaldehyde $(0.87 \%)$. Then, each sample was prepared in a histological slide and 1,000 pollen grains were counted under an optical microscope and the number of germinated and ungerminated grains was recorded.

\subsection{Interactions between bees and flowers}

In order to verify the number of open flowers found on each plant, flowering was followed through 120 plants, marked with coloured ribbons, distributed throughout the extremities (4 points) and throughout the inner portion of the field (8 points). In order to follow flowering progression, the number of flowers on each plant's main inflorescence was counted, twice a week, during the entire blooming period.

Interactions between bees and flowers were studied in temperature conditions above $12{ }^{\circ} \mathrm{C}$. The study was conducted for seven days, between June $24^{\text {th }}, 2007$ and July $22^{\text {nd }}, 2007$, during which $206 \mathrm{~A}$. mellifera individuals were observed at three different hours, in periods of 30 minutes, counted from 12:30 PM, 2:30 PM and 4:30 PM. Their behaviour was not evaluated in the morning due to low temperatures, which restricted their activities on the flowers. The following was recorded during the observations: (i) number of visited flowers per plant, (ii) time of permanence on flowers, (iii) contact with anthers and stigmas, and (iv) collected resources (nectar and/or pollen).

The types of pollen carried by A. mellifera were evaluated on 25 individuals having pollen stored in their pollen baskets, collected directly from the flowers on June $25^{\text {th }}$, June $1^{\text {st }}$ and July $25^{\text {th }}, 2007$, at three different times (12:00 PM, 2:00 PM and 4:00 PM), with an entomological net, and individually stored in flasks containing ethyl acetate. In order to homogenise pollen grains stored in corbiculae, pollen loads from one among each individual's pollen baskets was diluted in alcohol $70 \%$. Later, with one drop of these solutions, histological slides with glycerin/ fuchsine gelatin (Louveaux et al., 1978) were prepared and, under an optical microscope, 1,000 pollen grains from each sample were analysed, assessing their B. napus pollen percentage.

\section{Results}

\subsection{Anthesis and stigma receptivity}

B. napus flowers (see Figure 1-6) remained open and vigorous for approximately three days and, according to the conditions presented during their development, they were characterised in five anthesis stages (as shown in Table 1 and see Figure 2-6).

The dehiscence of anthers in the six stamens occurs during pre-anthesis. Thus, pollen availability is observed as soon as the flower opens (as shown in Table 1). The two short stamens release pollen grains under the stigma during the entire anthesis period and the four long stamens release the grains above it until the third stage, since the stigma reaches the stamens' height in the fourth stage. When the flower opens, the stigma is not yet receptive. The stigma presents itself receptive in the second and third stages of anthesis, period in which there is secretion on the stigmatic surface. When it ceases to be receptive, this secretion dries and causes the colour to change from yellow to dark beige. After the fourth stage of anthesis, the process of silique formation begins.

\subsection{Pollen grain viability}

Throughout this cultivar's anthesis, there was a visible decrease in pollen grain amounts, especially on Stage 4 flowers (having 72 hours). From cytoplasmic content analyses (see Figure 7) and the germination potential (see Figure 8) of pollen grains, it was verified that the viability average percentage decreased from the first to the last hours of anthesis (Phase 2 to 4), especially in the first test. It was verified that the grains maintained some viability for as much as 72 hours (see Figure 9).

\subsection{Interactions between bees and flowers}

Throughout the B. napus florescence period, the plants presented between $1-15$ open flowers $(\overline{\mathrm{x}}=5.04 ; \mathrm{sd}=2.45)$ and the bees visited from 1-7 flowers/plant $(\overline{\mathrm{x}}=2.02$; $\mathrm{sd}=1.16)$ during their foraging. Their time of permanence on one flower varied from 1 to 43 seconds $(\bar{x}=3.29$; $s d=2.36)$, being that, on those which they stayed longer than 10 seconds, the behaviour of discarding pollen adhered to the body was observed (1.2\% of the records), which was performed by their hanging on flowers and shaking until the excess pollen was released.

When seeking food resources, these honey bees presented intense foraging activities on the flowers. They touched flowers' anthers and stigmas on every visit. Nectar was the preferred resource by bees, being collected during all three evaluated periods. It was verified that the bees preferred collecting nectar from nectaries located in the inner part of short stamens, which were more easily accessible to them during the entire anthesis period.

The bees observed in flowers during the $2^{\text {nd }}$ and/or $3^{\text {rd }}$ period of anthesis, in the first observation period, sought both resources in the same flower and were active pollen collectors, being that the latter behaviour was also observed in the remaining periods, although more sporadically (see Figure 10). During hours in which there was no active pollen collection, this resource was passively obtained during the bees' displacement on the flowers. However, 

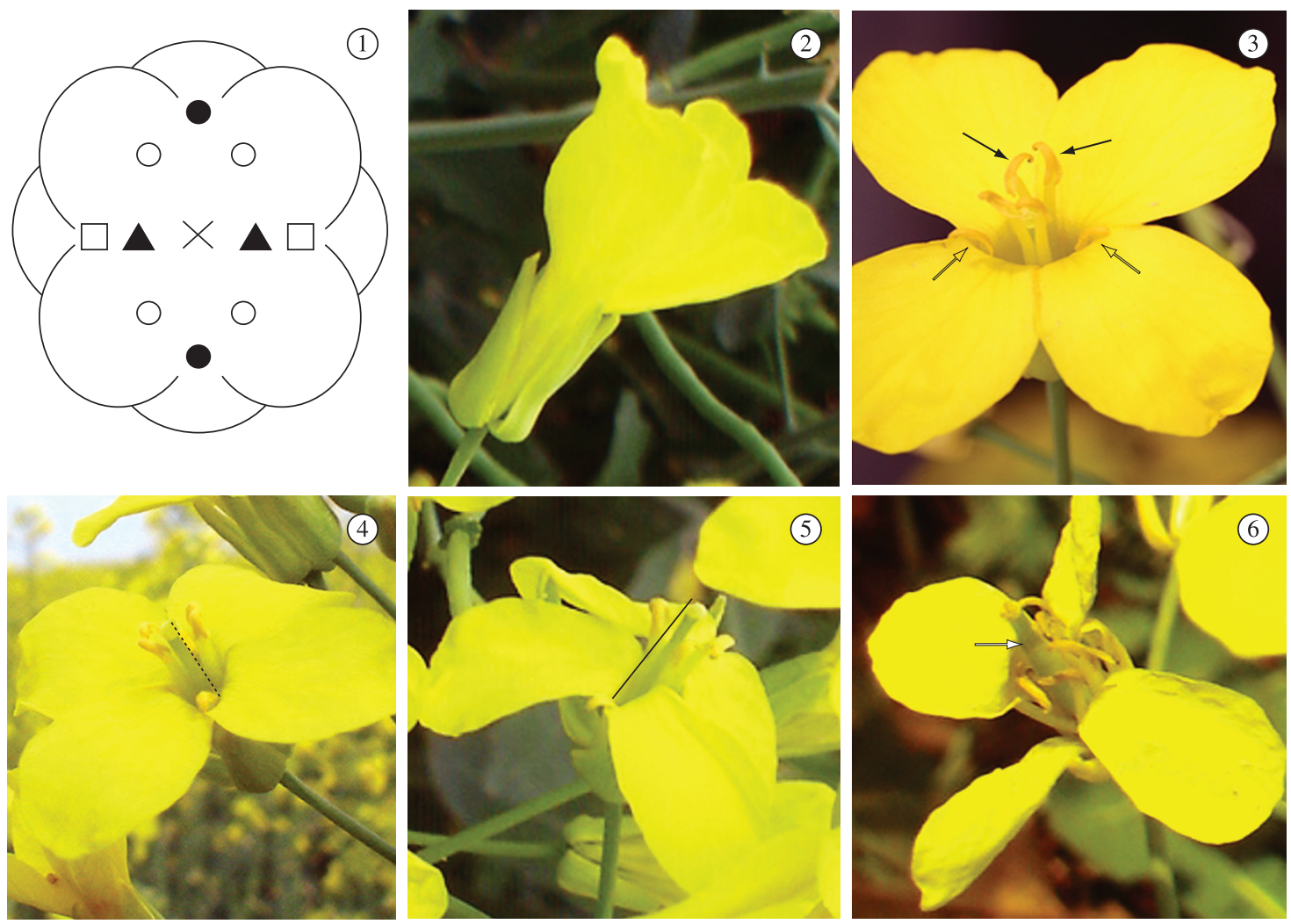

Figures 1-6. B. napus flowers: (1) schematics of a flower's reproductive elements; (x) stigma, (filled circles) nectaries between the pair of long stamens, (empty circles) long stamens, (triangles) nectaries inside short stamens, (squares) short stamens. Anthesis stages: (2) first stage; (3) second stage (filled arrows show long stamens and empty arrows show short stamens); (4) third stage (dashed line shows the growing pistil with stigma under the stamens); (5) fourth stage (line shows growing pistil and stigma reaching stamen height); (6) fifth stage (white arrow points to the pistil, which is higher than the anthers).

throughout their entire flower visitation periods, the bees stored great amounts of pollen in their corbiculae.

The analysis of pollen loads stored in pollen baskets revealed that the bees exclusively carried $B$. napus pollen.

\section{Discussion}

\subsection{Anthesis and stigma receptivity}

The flowers' morphophysiological development evidenced that the probability of self-pollination in the two short stamens is limited, since they release pollen grains under the stigma during the entire anthesis period. Concerning the four long stamens, self-pollination is only likely in the first stage of anthesis, since the stamens are above the stigma and bent inwards. However, at this point, the structure is not receptive. The stigma presents this condition in the second and third stages, periods in which the four long stamens are above it and bent outwards. Thus, coinciding with the high availability of pollen, flower morphology favors cross-pollination. This result indicates that, the action of pollinator agents is required during these two phases. Cross-pollination might be made by bees seeking of food resources on the flowers, or through pollen spread by the wind (Timmons et al. 1995). The possibility of pollination became nonviable as of the fourth stage of anthesis, as the stigma became unreceptive. These results constitute evidence of the occurrence of protandria in B. napus flowers (cv. Hyola 432).

Diverging results were found in tests developed by Mussury and Fernandes (2000) in the municipality of Dourados, Brazil, with cultivar CTC-4, and by Delaplane and Mayer (2000), in Georgia, USA, in which they concluded that, when the flower opens, its stigma is already receptive but the anthers are not yet dehiscent, verifying protogyny in the flowers. These two authors state that, within the studied cultivars, anther dehiscence occurs after the complete opening of the flower. Thus, until then, the flowers are only susceptible to cross-pollination, being that they only become susceptible to self-pollination during the complete opening of the flower.

Results obtained in this study, with Hyola 432 flowers, seem to agree with Abrol (2007), who concluded that the majority of Brassica species are self-incompatible to a certain point, but that this fact varies depending on the species, cultivar and plant age. Limitations to the occurrence of self-pollination were verified in all anthesis stages regarding the evaluated Hyola 432 flowers. Thus, the greater probability of cross-pollination, by A. mellifera 
Table 1. Stages of anthesis in flowers of B. napus (cv. Hyola 432).

\begin{tabular}{|c|c|c|c|c|c|c|c|c|}
\hline Phase & Corolla & $\begin{array}{c}\text { Pistil (mm) } \\
(\mathbf{x} ; \mathbf{s d})\end{array}$ & Stigma & $\begin{array}{c}\text { Long } \\
\text { stamens (4) }\end{array}$ & $\begin{array}{c}\text { Short } \\
\text { stamens (2) }\end{array}$ & $\begin{array}{c}\text { Pollen } \\
\text { availability }\end{array}$ & $\begin{array}{c}\text { Nectaries } \\
\text { between } \\
\text { long stamens }\end{array}$ & $\begin{array}{c}\text { Nectaries } \\
\text { between } \\
\text { short stamens }\end{array}$ \\
\hline $\begin{array}{c}1^{\text {st }} \\
\text { (12 hours) }\end{array}$ & $\mathrm{PO}$ & $6.84 ; 0.30$ & - & $\begin{array}{l}\text { Above the } \\
\text { stigma, bent } \\
\text { inwards }\end{array}$ & $\begin{array}{l}\text { Below the } \\
\text { stigma, bent } \\
\text { outwards }\end{array}$ & High & Hidden & Accessible \\
\hline $\begin{array}{c}2^{\text {nd }} \\
\text { (24 hours) }\end{array}$ & $\mathrm{FO}$ & $6.84 ; 0.31$ & + & $\begin{array}{l}\text { Above the } \\
\text { stigma, bent } \\
\text { outwards }\end{array}$ & $\begin{array}{l}\text { Below the } \\
\text { stigma, bent } \\
\text { outwards }\end{array}$ & High & $\begin{array}{l}\text { Partially } \\
\text { hidden }\end{array}$ & Accessible \\
\hline $\begin{array}{c}3^{\text {rd }} \\
\text { (48 hours) }\end{array}$ & $\mathrm{BS}$ & $7.99 ; 0.46$ & + & $\begin{array}{l}\text { Above the } \\
\text { stigma, } \\
\text { bent to the } \\
\text { outwards }\end{array}$ & $\begin{array}{l}\text { Below the } \\
\text { stigma, bent } \\
\text { outwards }\end{array}$ & High & Accessible & Accessible \\
\hline $\begin{array}{c}4^{\text {th }} \\
\text { (72 hours) }\end{array}$ & $\mathrm{S}$ & $8.25 ; 0.65$ & - & $\begin{array}{l}\text { Same height } \\
\text { as the } \\
\text { stigma, bent } \\
\text { outwards }\end{array}$ & $\begin{array}{l}\text { Below the } \\
\text { stigma, bent } \\
\text { outwards }\end{array}$ & Low & Accessible & Accessible \\
\hline $\begin{array}{c}5^{\text {th }} \\
\text { (96 hours) }\end{array}$ & $\mathrm{F}$ & $10.73 ; 0.81$ & - & $\begin{array}{l}\text { Below the } \\
\text { stigma }\end{array}$ & $\begin{array}{l}\text { Below the } \\
\text { stigma }\end{array}$ & None & Accessible & Accessible \\
\hline
\end{tabular}

B. napus flower anthesis stages (cv. Hyola 432). $\mathrm{PO}=$ partially open; $\mathrm{FO}=$ fully open; $\mathrm{BS}=$ beginning of the senescence; $\mathrm{S}=$ senescence; $\mathrm{F}=$ falling; (+) receptive; (-) non-receptive.
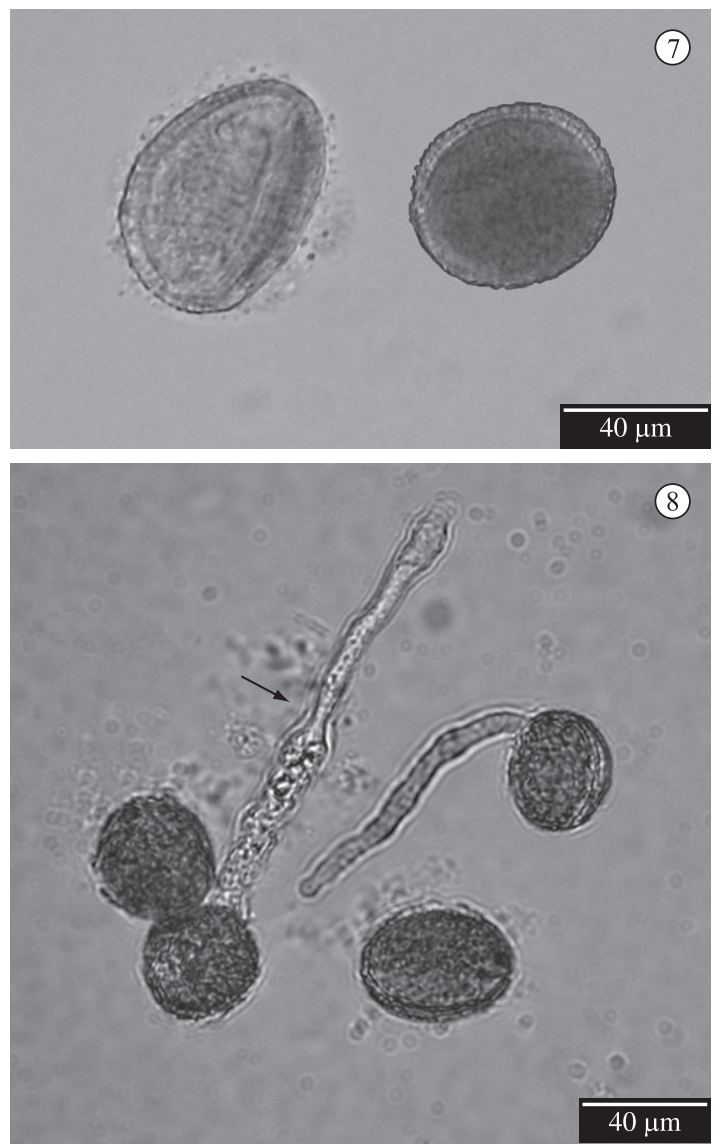

Figure 7-8. Pollen grains. (7) grains contrasted with aceticcarmine. (to the left, grain without cytoplasmic content, to the right, grain with cytoplasmic content); (8) grains in the culture medium (arrow indicates germinated pollen tube).

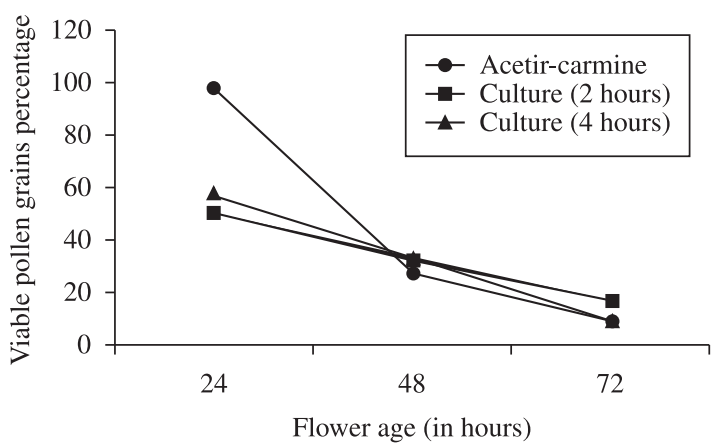

Figure 9. B. napus pollen grain viability percentage (cv. Hyola 432) according to flower age, in the three performed tests.

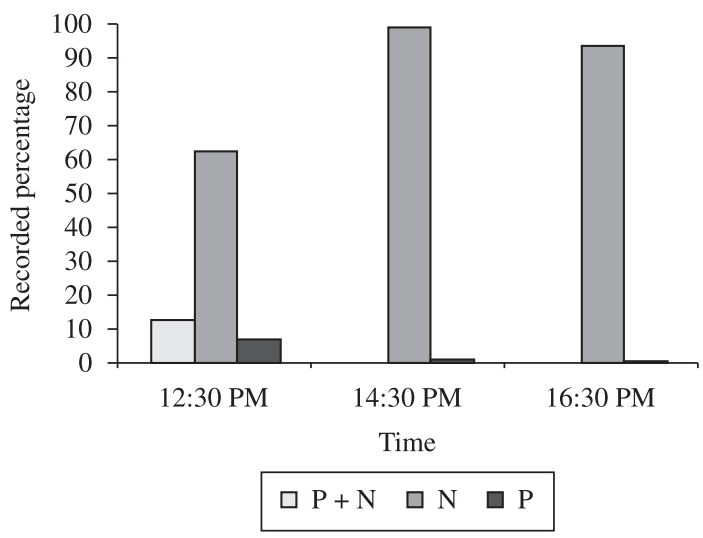

Figure 10. Resources collected by A. mellifera when visiting B. napus flowers (cv. Hyola 432). $\mathrm{P}=$ pollen; $\mathrm{N}=$ nectar. 
and other pollinator insects, enables a greater genetic variability for these cultivars.

\subsection{Pollen grain viability}

The decrease in the amount of pollen grains, especially on Stage 4 flowers, might be attributed to the senescence process, as well as to intense bee visitations while seeking food resources.

Similar results were verified by Bots and Mariani (2005), who verified some viability for 72 hours at most, from which a decrease of $35 \%$ in the average percentage of pollen grain germination was observed in young flowers (with dehiscent anthers and partially open corollas) and $15 \%$ in senescent flowers (after 72 hours).

According to Ockendon and Gates (1976) there is some difficulty in measuring pollen grain fertility and the available methods tend to overestimate its viability. According to these authors, the acetic-carmine method demonstrates that pollen which does not contain cytoplasm is certainly sterile, while pollen containing cytoplasm is not necessarily fertile. Thus, more accurate tests may present higher effectiveness and reveal lower averages, as do grain germination tests. This tendency was confirmed in this study, given that the germination index was approximately $50 \%$ lower in germination tests, when comparing the presence of cytoplasmic content. Honey bees tend to visit younger flowers (with dehiscent anthers and partially open corolla) more regularly than senescent flowers (Bots and Mariani, 2005), presenting, thus, a higher probability of viability for their transported pollen grains, since the highest viability percentages occur during the first hours of anthesis. Hence, it is suggested that these insects make an efficient pollination in B. napus flowers.

\subsection{Interactions between bees and flowers}

A. mellifera visited a small number of flowers per plant and spent little time on each flower, which differs from what was observed by Adegas and Nogueira-Couto (1992), who registered longer foraging periods on flowers. This behavioural difference might be attributed to the amount of flower resources offered to the pollinators, which probably varies according to the cultivar. Indeed, the reduced volume of nectar in the studied cultivar flowers, lower than $1 \mu \mathrm{l}$, made its collection impossible. This behaviour, observed in A. mellifera, seems to concur with a study developed by Cresswell (1999), who, while handling different amounts of nectar, concluded that visiting periods of Bombus lapidarius on flowers increased when levels of nectar were higher.

Bees that stayed longer than 10 seconds on flowers presented the behaviour of discarding pollen grains attached to their body. According to Thorp (2000) sometimes the bees' bodies become overloaded while moving amongst flowers due to passive pollen collection. The author states that, in such cases, these insects present the behaviour of discarding the excess pollen, so they may become lighter in order to perform flight activities. Williams (1980) verified the same discarding behaviour. Concerning the bees observed on Hyola 432 flowers, this discarded pollen represents a small percentage, therefore their visits to a small number of flowers/plant, their brief permanence on flowers and their contact with anthers and stigmas favour cross-pollination.

The bees touched flower anthers and stigmas in all visits, favoring cross-pollination; this happens because their body size is compatible to the flower size, as well as to its landing behaviour and displacement on the flower. Since these insects insert their heads into the flower in order to suck nectar, body hairs touch the anthers and adhere to pollen grains. When they fly to another flower, the grains detach and fall on the stigma, which favours cross-pollination.

The bees' preference for nectar collection coincides with results obtained by Williams (1980); Adegas and Nogueira-Couto (1992); Free and Nuttal (1968), in which they verified the active collection of this resource throughout the day. The results of this study are reinforced by Williams (1980), who states that the bees take more benefit from inner nectaries, because they are not only more easily accessible but also secrete a larger amount of nectar and have higher sugar concentrations. In addition, they also reinforce low percentages of active pollen collections, stating that the bees never sought this resource, exclusively, while foraging on B. napus crops. According to Malerbo-Souza et al. (2008) the highest frequency of nectar collection compared to pollen collection is directly related to the insects' high energetic demands during their foraging, since this resource's carbohydrates stimulate their flying activity.

The composition of bee pollen loads is essential in order to verify their foraging habits and, after analysing pollen contents from their pollen baskets, we could infer their efficiencies as pollinators of certain plant species (Wittmann and Schlindwein, 1995). The constancy of A. mellifera on the target-species, B. napus, might be justified by the abundance of nectar and pollen throughout the day.

The foraging behaviour of honey bees, characterised by their visits to a small number of flowers/plant, their brief time of permanence on flowers and their contact with anthers and stigmas, along with their floral constancy, allows us to consider them as potential B. napus pollinators.

Acknowledgements - We would like to thank professors Marcos Garrafa, Valdir Benedetti and Dalziro Valdameri for allowing the execution of fieldwork at SETREM; professor Leandro Vieira Astarita for helping during the preparation of materials for pollen analysis; Lucas Lima Fontana for image editing; Ione Maria de Souza Rosa and Andressa Paladini for helping out during field data gathering; Maria Isabel Behs de Araújo for reviewing the manuscript; $\mathrm{CNPq}$ (National Council for Scientific and Technological Development) for granting a Master's scholarship (Programa de Pós Graduação em Zoologia, PUCRS) to the first author (Proc. 131357/2007-7); and PUCRS for making its facilities available for the execution of this research project.

\section{References}

ABROL, DP., 2007. Honeybees rapeseed pollinator plant interaction. Advances in Botanical Research, vol. 45, p. 337-369.

ADEGAS, JEB. and NOGUEIRA-COUTO, RH., 1992. Entomophilous pollination in rape (Brassica napus L. var oleifera) in Brazil. Apidologie, vol. 23, no. 1, p. 203-209. 
ALBUQUERQUE, GA., 2006. Avaliação reológica e caracterização físico-química do biodiesel de canola e misturas. Available from: <http://www.biodiesel.gov.br/docs/congressso2006/Armazenamento/ AvaliacaoReologica3.pdf>. Access in: 20/07/2008.

ALBUQUERQUE, GA., SOUZA, MA., ANDEIA, RA., DANTAS, MB., SILVA, MCD., SANTOS, IMG. and SOUZA, AG., 2007. Compatibilidade térmica dos biodieseis da canola, milho, soja e misturas: uma avaliação termogravimétrica. Available from: <http:// www.biodiesel.gov.br/docs/congresso2007/caracterizacao/15. pdf>.Access in: 08/09/2008.

BARNI, ND., HILGERT, ER., ZANOTELLI, V., VARGAS, JNR., TEDESCO, A., BOHN, D., GOMES, JES. and GONÇALVES, JC., 1985. Introdução e avaliação de cultivares de colza (Brassica napus L. var. oleifera Metzg.) no Estado do Rio Grande do Sul. Agronomia Sulriograndense, vol. 21, p. 21-54.

BOTS, M. and MARIANI, M., 2005. Pollen viability in the field. Available from: <www.cogem.net/ContentFiles/Pollen_viability. pdf $>$. Access in: 23/05/2008.

CORBET, SA., WILLIAMS, IH. and OSBORNE, JL., 1991. Bees and the pollination of crops and wild flowers in the European Community. Bee World, vol. 72, p. 47-59.

CRESSWELL, JE., 1999. The influence of nectar and pollen availability on pollen transfer by individual flowers of oil-seed rape (Brassica napus) when pollinated by bumblebees (Bombus lapidarius). Journal of Ecology, vol. 87, no. 4, p. 670-677.

CUNHA, GR., 2007. Agroenergia: o futuro que chegou. Passo Fundo: O Nacional. 52 p.

DAFNI, A., KEVAN, PG. and HUSBAND, BC., 2005. Practical pollination biology. Canada: Enviroquest. 590 p.

D'ÁVILA, M. and MARCHINI, LC., 2005. Polinização realizada por abelhas em culturas de importância econômica no Brasil. Boletim de Indústria Animal, vol. 62, no. 1, p. 79-90.

DELAPLANE, KS. and MAYER, DF., 2000. Crop Pollination by bees. USA: CABI Publishing. $344 \mathrm{p}$.

EARDLEY, C., ROTH, D., CLARKE, J., BUCHMANN, S. and GEMMILL, B., 2006. Pollinators and Pollination: a resource book for policy and pratice. Africa: African Pollinator Initiative. 77 p.

EISIKOWITCH, D., 1981. Some aspects of pollination of oil seed rape (Brassica napus L.). Journal of Agricultural Science, vol. 96 , p. 321-326.

FAEGRI, K. and PIJL, VD., 1979. The principles of pollination ecology. Oxford: Pergamon Press. 244 p.

FLORES, LRF. and TRINDADE, JLF., 2007. Importância da polinização entomófila em diferentes culturas de interesse econômico para o Brasil. Available from: <http://www.pg.cefetpr. br/setal/docs/artigos/2007/polinizacao_entomofila.pdf > . Access in: $15 / 10 / 2008$.

FREE, JB., 1993. Insect pollination of crops. London: Academic Press. 684 p.

FREE, JB. and NUTTALL, PM., 1968. The pollination of oilseed rape (Brassica napus) and the behaviour of bees on the crop. Journal of Agricultural Science, vol. 71, p. 91-94.

FREITAS, BM. and PAXTON, RJ., 1996. The role of wind and insects in cashew (Anacardium occidentale) pollination in NE Brazil. Journal of Agricultural Science, vol. 126, p. 319-326.

Gene Technology Regulator, 2002. The biology and ecology of canola (Brassica napus). Available from: <http://www.ogtr.gov. au/pdf/ir/brassica.pdf $>$. Access in: 18/03/2008.
IMPERATRIZ-FONSECA, VL., 2004. Serviços aos ecossistemas, com ênfase nos polinizadores e polinização. Available from: <http:// www.ib.usp.br/vinces/logo/servicos\%20aos\%20ecossistemas polinizadores_vera.pdf>. Access in: 13/05/2008.

KEVAN, G. and EISIKOWITCH, D., 1990. The effects of insect pollination on canola (Brassica napus L. cv. O. A. C. Triton) of seed germination. Euphytica, vol. 45, p. 39-41.

LOUVEAUX, J., MAURIZIO, A. and VORWHL, G., 1978. Methods of melissopalynology. Bee World, vol. 59, no. 4, p. 139-157.

MALERBO-SOUZA, DT., TOLEDO, VAA. and PINTO, AS., 2008. Ecologia da polinização. São Paulo: Editora CP2. 31 p.

MASIEROWSKA, ML., 2003. Floral nectaries and nectar production in brown mustard (Brassica juncea) and white mustard (Sinapis alba) (Brassicaceae). Plant Systematics and Evolution, vol. 238, p. 97-107.

MCGREGOR, SE., 1976. Insect pollination of cultivated crop plants. Washington: USDA. 411 p.

MESQUIDA, J., MARILLEAU, R. and PHAM-DELEGUE, M., 1988. A study of rapeseed (Brassica napus L. var. oleifera Metzger) flower nectar secretions. Apidologie, vol. 19, no. 3, p. 307-318.

MUSSURY, RM. and FERNANDES, W., 2000. Studies of the Floral Biolgy and Reproductive System of Brassica napus L. (Cruciferae). Brazilian Archives of Biololgy and Technology, vol. 43, no. 1, p. 111-117.

OCKENDON, DJ. and GATES, PJ., 1976. Reduced pollen viability in the onion (Allium cepa). New Phytologist, vol. 76, p. 511-517.

SABBAHI, R., OLIVEIRA, D. and MARCEAU, J., 2005. Influence of Honey Bee (Hymenopetra: Apidae) Density on the Production of Canola (Cruciferae: Brassicaceae). Journal of Economic Entomology, vol. 98, no. 2, p. 367-372.

SCHLINDWEIN, C., WITTMANN, D., MARTINS, CF., HAMM, A., SIQUEIRA, JA., SCHIFFLER, D. and MACHADO, C., 2005. Pollination of Campanula rapunculus L. (Campanulaceae): how much pollen flows into pollination and into reproduction of oligolectic pollinators? Plant Systematics and Evolution, vol. 250 , p. $147-156$

SYAFARUDDIN, HORISAKI, A., NIIKURA, S., YOSHIOKA, Y. and OHSAWA, R., 2006. Effect of floral morphology on pollination in Brassica rapa L. Euphytica, vol. 149, p. 267-272.

THORP, RW., 2000. The collection of pollen by bees. Plant Systematics and Evolution, vol. 222, p. 211-223.

TIMMONS, AM., O'BRIEN, ET., CHARTERS, YM., DUBBELS, SJ. and WILKINSON, MJ., 1995. Assessing the risks of wind pollination from fields of genetically modified Brassica napus ssp. oleifera. Euphytica, vol. 85, p. 417-423

TOMM, GO., 2005. Situação em 2005 e perspectivas da cultura de canola no Brasil e em países vizinhos. Available from: $<$ http://www.cnpt.embrapa.br/biblio/bp/p_bp26.htm>. Access in: $17 / 03 / 2008$

WILLIAMS, IH., 1978. The pollination requirements of swede rape (Brassica napus L.) and turnip rape (Brassica campestris L.). Journal of Agricultural Science, vol. 91, p. 343-348.

WILLIAMS, IH., 1980. Oilseed rape and beekeeping particularly in Britain. Bee World, vol. 61, p. 141-153.

WITTMANN, D. and SCHLINDWEIN, D., 1995. Melittophilous plants, their pollen and flower visiting bees in southern Brazil. 1. Losaceae. Biociências, vol. 3, no. 2, p. 19-34. 
